\title{
The Determinants of Micro, Small and Medium Enterpreneur (MSME) Become Customer of Islamic Banks (Religion, Religiousity and Location of Islamic Banks)
}

\author{
Yudhi Herliansyah ${ }^{1}$, Lucky Nugroho ${ }^{2}$, Denanda Ardilla ${ }^{3}$, Yananto Mihadi Putra ${ }^{4}$ \\ \{yudhi.herliansyah@mercubuana.ac.id ${ }^{1}$, lucky.nugroho@mercubuana.ac.id ${ }^{2}$, \\ denandaardilaa@gmail.com ${ }^{3}$, yananto.mihadi@mercubuana.ac.id $\left.{ }^{4}\right\}$ \\ Universitas Mercu Buana, Indonesia ${ }^{1234}$
}

\begin{abstract}
The purpose of this study was to find out the reasons for Micro Small Medium Entrepreneur (MSME) in making decisions to become sharia bank customers. Factors suspected of influencing decision making are religions, religiosity, and location of Islamic banks. The method used is quantitative which is limited by research questions (1) How is the relationship of religion to being a customer of Islamic banks (2) How is the relationship of religiosity by being a customer of Islamic banks (3) How is the location of being a customer of Islamic banks. Based on the results of the study, religion, religiosity, and location have a positive and significant influence on the decision to become Islamic bank customers. Whereas location has a negative and not significant influence. This shows that the higher the religion and religiosity of MSME entrepreneurs, then they will tend to make Islamic banks as their financial transactions. In contrast to the location, the farther away from the location of the Islamic bank from the place of residence or place of business, then they tend not to use the Islamic bank.
\end{abstract}

Keywords: Religion, Religiosity, Location, Islamic Bank.

\section{Introduction}

In line with economic growth in Indonesia, which reached 6.5\% In 2011, also the increase in economic transactions and increased income in the community of a country, hence increasing the role of banks through the development of banking products and services. The banking sector in Indonesia continues to expand its business by opening offices in various parts of Indonesia. The development of the number of conventional banks was 120 banks at the end of 2011, with the number of 14,797 offices spread throughout Indonesia (1). The backbone of the economy in many developing countries, including Indonesia, are micro, small and medium enterprises (MSMEs). In addition to being the frontline in the MSME economy, it is also a strategic forum for providing independent workers who are free from dependence on other parties. Indonesia currently continues to strive and continues to strive to improve the economy for the sake of increasing the level of prosperity for its people (2).

When the economic crisis hit the world automatically, it also worsened economic conditions in Indonesia. From 1997 to 1998, the condition of the crisis occurred, only the MSME sector (Micro, Small, and Medium Enterprises) was able to remain standing firm (3- 
6). Data from the Central Statistics Agency released the situation after the economic crisis of the number of MSMEs at that time did not decrease. Instead, the growth was increasing, even able to absorb 85 million to 107 million workers until 2012. In that year, the number of entrepreneurs in Indonesia was 56.539.560 units, which MSMEs amounted to 56.534.592 units or $99 \%$. The remaining around $0,01 \%$ or 4968 units is a large scale business. This phenomenon can also explain that MSMEs are productive businesses to be developed to support macro and microeconomic development in Indonesia and influence other sectors to develop. From the growth of MSMEs, One of the sectors affected is the banking services sector which is also affected because almost $30 \%$ of MSME businesses use operational capital from banks (7).

Traditional markets are markets that are built and managed by the Regional Government. Local, private, state-owned and regional-owned enterprises include cooperation between the private sector and business places in the form of shops, kiosks, booths, and tents owned or managed by small, medium-sized, non-governmental organizations or cooperatives with small-scale businesses, selling processes buying merchandise can also be done through bargaining with small capital $(8,9)$. The existence of the market, especially traditional markets, is one of the most obvious indicators of community economic activity in a region. The government must pay attention to the existence of traditional markets as one of the public facilities that can support community economic activities. The development of times and changes in human lifestyles that have been promoted so actively by various media have made the existence of traditional markets a little disturbed. However, traditional markets during the modern market invasion in various forms turned out that traditional markets were still able to survive and compete [22].

The Financial Services Authority (OJK), through the Director of Research, Development, Arrangement, and Licensing of OJK Sharia Banking Dhani Gunawan, told Investor Daily in Jakarta stated that at present, the total number of sharia banking customers reaches around 15 million. Meanwhile, conventional banking customers touch around 80 million people. The total number of new sharia bank customers reached 18.75 percent compared to conventional banks, and this shows a positive response from people using Islamic banking services and services making Islamic banks continue to multiply. The phenomenon can see from a large number of offices or the emergence of Islamic banks in Indonesia and already present in 34 provinces throughout the archipelago. It is not only Islamic banks that get a positive response from the Islamic community in Indonesia that is known to be religious, of course, financial institutions that use the sharia system also get a positive response (10).

Based on these problems, the understanding of consumer behavior, in this case, banking customers are becoming increasingly crucial and exciting to study. So that this research was conducted to find out whether there is an influence between religion, religiosity, and location on the decision to become a customer of Islamic banks.

\section{Literature Review/Theoretical Framework and Hypothesis Development}

\subsection{The Role of Sharia Banks Against Social Welfare}

In the economics of the state, banking is one of the agents of development (agent of development), because the primary function of banking is as an intermediary financial 
institution. The bank function is to collect funds from the public in the form of deposits and redistribute them to the community in the form of credit or financing. The function of banking as an intermediary financial institution is also a concern of Islamic banking, besides being an institution that manages zakat, infaq, and shodaqoh (ZIS) $(11,12)$.

Thus the Bank plays a vital role in driving the national economy because banks are fund collectors from surplus units and credit channelers to unit deficits. Banks are an effective and productive savings place for the community and facilitate payment traffic for all sectors of the economy. The existence of Islamic banking as part of the national banking system is expected to drive the economic development of a country. Islamic banks in the economy aim and function for economic prosperity in a broad sense, full employment and optimum economic growth, socio-economic justice and equitable distribution of income and wealth, stability in the value of money, mobilization and investment savings that guarantee fair returns and effective services (13). This is due to the application of the anti-Maysir (Speculation/Gambling) anti-sunset principle, Gharar (uncertainty) and usury so that Islamic banks have the following principles $(13,14)$ :

- Brotherhood (ukhuwah);

- Justice;

- Benefit;

- Balance (tawazun);

- Universalism (syumuliyah).

\subsection{Religious Factors Against the Decision to Become Customers of Islamic Banks}

Religion is a belief system that is united by practices related to sacred things, things that are permitted and prohibited, beliefs, and practices that unite moral communities called Mosques, Churches, Temples, Temples. This shows that religion as a belief has a broad meaning, religion, on the one hand, is referred to as a belief system by establishing rules of worship rituals that are carried out and on the other hand religion also as a system that is comprehensive and covers all aspects of life, including economic development problems and the banking industry as one of the driving forces of the economy (15).

Islamic banking or Islamic banking is a banking system developed based on sharia (Islamic law). The effort to establish this system is based on the prohibition in Islamic religion to collect or borrow with interest, or in other words, usury. This is further reinforced by the opinion of the scholars in Indonesia represented by the number 12004 MUI fatwa on the interest, which essentially prohibits bank interest in which there are usury elements. The prohibition on usury collection, which is the main feature of Islamic banks, also turns out to have roots in the teachings of non-Islamic religions (13). Prohibition of usury collection, as found in the Qur'an QS. Al-Baqarah 2: 275-276, it turns out we can also find in the Englishlanguage Gospel revised edition, Exodus 22:25 and Eutronomy 23: 19-20. The concept of usury in Hinduism and Buddhism is found in the Laws of Manu, while the concept of Jewish usury is found in Exodus 22: 25 and Leviticus 25: 35-37 (13,16).

\subsection{Religiosity Factors Against the Decision to Become a Customer of a Sharia Bank}

Religious values that have entered into human beings are also called religiosity, which later plays a significant role in efforts to develop human character. That is why in the history of the nations of the world, many religions teach virtue is a manifestation of ideas to make 
honest and pious people in the future. It cannot be denied that there are still many individuals who lead religious lives in functional rankings. Religion is only used for other purposes that are not religious. Religion is only used in times of anxiety, during routine ceremonies, and so on, even though religious awareness should exist comprehensively in human life (17). At the beginning of the growth of Islamic banking as if religious motives were the main factor that encouraged customers to choose Islamic banks. However, in the face of competition with conventional banks other factors such as technology, customer service is also a determinant of the existence and development of Islamic banks (18).

\subsection{Location Factors Against Decision To Become Customers of Sharia Banks}

Location plays an important role in the decision to purchase a product or service product. Customers may not look for products that are located outside the customer's reach. Of course, this will make customers think they can spend time, energy, and money (19). Therefore, the location factor where the product or service product in the company is highly dependent on the purchasing decision by the customer. The purpose of the bank location is where the products of the bank branch are traded and the banking control center. In practice, there are several types of bank office locations, namely the location of the head office, the main branch, the auxiliary branch, the cash office, and the location of the Automated Teller Machines (ATM).

\subsection{Previous research}

The Influence of Knowledge and Religion, Salatiga's college About Islamic Banking Systems against the Interest in Saving in Islamic Banks". The results of the research are knowledge variables have significant, and variable religion has a significant influence to open saving account in Islamic Bank (20). Aditya Putra Pratama Prihandono conducted similar research (2017) entitled "Analysis of the Effect of Knowledge, Religiosity and Rational Motives on Lecturers' Decision Processes Using Islamic Banks (Case Study of Syarif Hidayatullah UIN Lecturers in Jakarta)." The results indicate that there is significant influence between knowledge variables, religiosity variables, and rational motive variables towards the lecturer decision process using Islamic Bank products and services (21). Another similar research was carried out by Indra Utama (2017) entitled "The Effect of Product Quality, Religiosity, Promotion Mix, and Location on the Decision Process of Becoming BNI Syariah Branch IB Hasanah Savings Customers." This study showed that product quality partially had a significant effect, religiosity has an effect, and the promotion mix partially (location) has a significant negative effect on the customer's decision process (21).

\subsection{Hypothesis}

The hypothesis is a temporary answer to a problem that still needs to be verified and must be logical, clear, and testable. The following are hypothesis formulations, including:

H1: Religious factors influence the decision of MSME to use Islamic banking services

$\mathrm{H} 2$ : Religiosity factor influences the decision of MSME to use Islamic banking services

H3: Location factors influence the decision of MSME to use Islamic banking services Related to the hypothesis, thus the formulation of this article as follows:

$M S M E=\alpha+\beta 1 A+\beta 2 R+\beta 3 L+\varepsilon$

Remark:

MSME: Micro, Small and Medium Entrepreneurs (MSME) that engage with Islamic Bank 


\author{
$\alpha: \quad$ Coefficient \\ A: $\quad$ MSME religion \\ R: $\quad$ MSME Religiosity \\ L: $\quad$ Location distance between the MSME home or their shop to the Islamic Bank outlet
}

\title{
3 Research Methods
}

\subsection{Data Collection Techniques}

The type of data used in this study is primary and secondary data. Primary data is obtained by distributing questionnaires, while secondary data is obtained from journals and other literature studies related to this study.

\subsection{Population and Sample Collection Techniques}

The population in this study is MSME located in the East Cengkareng Sub-District of West Jakarta, where the number of entrepreneurs is 125 people.

\subsection{Research variable}

The variables used in this study are divided into two, namely the independent variable and the dependent variable. Independent variables consist of religion, religiosity, and location. Meanwhile, the dependent variable is the decision to become a customer of a Sharia Bank.

\subsection{Data analysis method}

The analytical method used is by using logistic regression analysis. The data obtained is processed using SPSS. Data analysis tools in the form of data quality test (including validity and reliability test), feasibility test regression models, assessing the overall model (overall model fit), determination coefficient test (Nagelkerke $r$ square), Multicollinearity Test, Classification Matrix. Logistic regression analysis aims to determine the effect of independent variables, namely religion, religiosity, and location on the customer's decision to use Islamic banking services aimed at analyzing the effect of independent variables on the dependent variable.

\section{Analysis and Discussion}

\subsection{Analysis of Data Validity and Reliability}

A validity test is done to test the validity of the questionnaire used to measure a variable. From the results of the testing carried out using SPSS 20, the results obtained show that all indicators used to measure variables are valid. The conclusion that the variables tested have been valid is obtained from the results of the Corrected Item Total Correlation, whose value is more than 0.05 . While the reliability test is done to determine the reliability of the questionnaire that has been distributed in measuring a variable. The results obtained are that 
Cronbach's Alpha is equal to 0.815 so the question items to get the value are said to be reliable or reliable with very high criteria.

\subsection{Test the Assumptions and Quality of Research Instruments}

\section{Feasibility Test of the Goodness of Fit Test.}

Hosmer and Lemeshow's Goodness of Fit Test is used to determine the size of the model determination used and measure the accuracy of the regression line in carrying out variations in the value of independent variables. Hosmer and Lemeshow's Goodness of Fit Test is used to test the feasibility of a logistic regression model.

Table 2: Regression Model Feasibility Test Results

\begin{tabular}{|l|r|r|r|}
\hline Hosmer and Lemeshow Test \\
\hline 1 & Chi-square & df & \multicolumn{1}{c|}{ Sig. } \\
\hline
\end{tabular}

Output SPSS 20

In table 2 above shows the Chi-square value of 15.177 with a significance value of 0.056 . Based on these results, the significance value is more than 0.05 , and it means that the model can predict the amount of observation.

\section{Determination Coefficient Test ( Nagelkerke $R$ Square )}

The coefficient of determination (R2) aims to measure how far the model's ability to explain variations in the dependent variable. The purpose of this model is to find out how much the combination of independent variables consisting of religion, religiosity, and location can explain the dependent variable, namely the decision to become an Islamic bank customer (table 3).

Table 3 Determination Coefficient Test Results

\begin{tabular}{|l|r|r|c|}
\hline Step & -2 Log likelihood & $\begin{array}{c}\text { Cox \& Snell R } \\
\text { Square }\end{array}$ & $\begin{array}{l}\text { Nagelkerke R } \\
\text { Square }\end{array}$ \\
\hline 1 & $155.061^{\mathrm{a}}$ & .136 & .181 \\
\hline
\end{tabular}

a. Estimation terminated at iteration number 4 because

parameter estimates changed by less than .001 .

Based on table 3, the coefficient of determination in the logistic regression model is shown by the value of Nagelkerke R Square. Nagelkerke R Square value is 0.181 , which means that the variability of the dependent variable that can be explained by the independent variable is $18.1 \%$, while other variables outside the research model explain the remaining $81.9 \%$. 


\section{Logistic Regression Test}

The test results on the regression coefficients produce the following models (table 4):

Table 4 Logistic Regression Coefficient Test Results

\begin{tabular}{|c|c|c|c|c|c|c|c|}
\hline \multicolumn{8}{|c|}{ Variables in the Equation } \\
\hline & & $\mathrm{B}$ & S.E. & Wald & df & Sig. & $\operatorname{Exp}(B)$ \\
\hline \multirow{4}{*}{ Step $1^{\mathrm{a}}$} & Religion & .342 & .108 & 10.121 & 1 & .001 & 1.408 \\
\hline & Religiosity & -.246 & .119 & 4.295 & 1 & .038 & .782 \\
\hline & Location & .130 & .067 & 3.778 & 1 & .052 & 1.139 \\
\hline & Constant & -5.751 & 2.015 & 8.143 & 1 & .004 & .003 \\
\hline
\end{tabular}

a. Variable(s) entered on step 1: Religion, Religiosity, Location.

Test results on the regression coefficients produce the following models:

$$
\text { MSME }=-5,751+0,342 \mathrm{~A}-0,246 \mathrm{R}+0,130 \mathrm{~L}
$$

Referring to the results of data processing using SPSS version 20 statistical tools, the hypotheses are shown in table 1 below:

Table 5 Summary of results of hypothesis testing:

\begin{tabular}{clcl} 
Code & \multicolumn{1}{c}{ Hypothesis } & $\begin{array}{c}\text { Logistic } \\
\text { Regression Test } \\
\text { Results }\end{array}$ & Results \\
\hline H1 & $\begin{array}{l}\text { Religion factors have a significant effect on } \\
\text { customer decisions using voluntary Islamic } \\
\text { banking services }\end{array}$ & $\mathbf{0 . 0 0 1}$ & Accepted \\
\hline $\mathbf{H 2}$ & $\begin{array}{l}\text { Religiosity factors have a significant effect on } \\
\text { customer decisions using voluntary Islamic } \\
\text { banking services }\end{array}$ & $\mathbf{0 . 0 3 8}$ & Accepted \\
\hline $\mathbf{H 3}$ & $\begin{array}{l}\text { Location factors have a significant effect on } \\
\text { customer decisions using voluntary Islamic } \\
\text { banking services }\end{array}$ & $\mathbf{0 . 0 5 2}$ & $\begin{array}{l}\text { Not } \\
\text { accepted }\end{array}$ \\
\end{tabular}

According to statistical results in this study, religion influences the customer's decision to use Islamic banking services. The logistic regression test results show that religious factors have a significance value of 0.001 , which means hypothesis 1 (H1) is acceptable because the significance value is smaller than 0.05 . So it can be concluded that $\mathrm{H} 1$ was successfully supported and accepted. Some researchers in the past, also stated that religious variables have a significant influence on customers to use Islamic banking products and services $(22,23)$. Furthermore, belief in religion will have an impact on behavior. Therefore, when someone is Muslim decides to use Islamic bank products and services, it is their duty to carry out their religious teachings in totality (kafah) $(12,24-27)$. 
Furthermore, the statistical results in this study note that religiosity has a significant effect on customer decisions using the services of Islamic banks. The test results from the logistic regression show that the religiosity factor has a significance value of 0.038 because the significance value is smaller than 0.05 , then hypothesis $2(\mathrm{H} 2)$ is accepted. The more obedient in carrying out the teachings of his religion, the individual has good self-control in himself (religious). Religion can control all human behavior, one of which is the behavior in determining to become a customer with an Islamic bank. So someone who carries out orders and avoids prohibitions from Allah SWT will increase the chances of that person becoming a customer of an Islamic bank (28-30).

The output of this study, location does not have a significant effect on customer decisions to use the services of an Islamic bank. The test results from logistic regression show that the location factor has a significance value of 0.052 , which means that $\mathrm{Ha}$ is rejected because the significance value is higher than 0.05 . Thus, if someone has a good religious, then location is not a problem for them. MSME's belief and devotion will move them to become customers of Islamic banks.

\section{Conclusion}

Based on the results of the research and discussion, the conclusions are as follows: (i) The test results show that the Religion variable (X1) influences the MSME decision to use Islamic banking services. This shows that Islamic banks will get customers if the majority of the people are Muslim; (ii) The test results show that the Religiosity variable; (X2) influences the MSME decision to use Islamic bank services. This shows that Islamic banks will get customers if Islamic banks do marketing in places of worship, Islamic radio, and other public religious facilities; (iii) The test results show that the Location variable (X3) not significantly influence the MSME decision to use Islamic bank services. This shows that Islamic banks will get customers if Islamic banks expand the network of Islamic bank branch offices and the spread of ATMs, also a digital branch, to make more accessible the community to access Islamic banks.

\section{References}

1. Murdiyanto A. Faktor-Faktor Yang Berpengaruh Dalam Penentuan Penyaluran Kredit Perbankan. In: Conference in Business, Accounting and Management (CBAM). Semarang; 2012. p. 61-74.

2. Djakfar M. Makna Kerja Bagi Pengusaha Kecil Muslim Di Tengah Perkembangan Bisnis Kuliner. J Al Hikam. 2015;10(2):410-33.

3. Nugroho L, Utami W, Akbar T, Arafah W. International Journal of Energy Economics and Policy The Challenges of Microfinance Institutions in Empowering Micro and Small Entrepreneur to Implementating Green Activity. Int J Energy Econ Policy [Internet]. 2017;7(3):66-73. Available from: http:www.econjournals.com

4. Sudarsono H. Dampak Krisis Keuangan Global terhadap Perbankan di Indonesia: Perbandingan antara Bank Konvensional dan Bank Syariah. La_Riba [Internet]. 2009;3(1):12-23. Available http://jurnal.uii.ac.id/index.php/JEI/article/view/2551

5. Nugroho L, Lutful S, Chowdhury K. Mobile Banking for Empowerment Muslim Women Entrepreneur: Evidence from Asia (Indonesia and Bangladesh). Tazkia Islam Financ Bus Rev. 2015;9(1):83-100. 
6. P Eko Prasetyo. Peran Usaha Mikro Kecil dan Menengah (UMKM) dalam Kebijakan Penanggulangan Kemiskinan dan Pengangguran. AKMENIKA UPY. 2009;2.

7. Suci YR. Perkembangan UMKM (Usaha Mikro Kecil dan Menengah) di Indonesia. J Ilm Cano Ekon. 2017;6(1):51-8.

8. Kuntjara E. Gender and Assertiveness : Bargaining in the Traditional Market in East Java: WL WL. Women Lang. 2005;28(1):54-61.

9. Khuri FI. The Etiquette of Bargaining in the Middle East. Am Anthropol. 1968;70(4):698-706.

10. Sutami WD. Strategi Rasional Pedagang Pasar Tradisional. BioKultur. 2005;11(2):127-48.

11. Nugroho L, Wiwik U, Citra S, Tettet F. The Urgency of Allignment Islamic Bank to Increasing the Outreach. Int J Econ Financ Issues [Internet]. 2017;7(4):283-91. Available from: https://www.econjournals.com/index.php/ijefi/article/view/4493/pdf

12. Nugroho L, Hidayah N, Badawi A. The Islamic Banking, Asset Quality: "Does Financing Segmentation Matters" (Indonesia Evidence). Mediterr J Soc Sci. 2018 Jan 8;9(5):221-35.

13. Sukmadilaga C, Nugroho L. Pengantar Akuntansi Perbankan Syariah "Prinsip, Praktik dan Kinerja.” Pusaka Media, Bandar Lampung, Indonesia; 2017. 292 p.

14. Nugroho L, Badawi A, Hidayah N. Discourses of sustainable finance implementation in Islamic bank (Cases studies in Bank Mandiri Syariah 2018). Int J Financ Res. 2019;10(6):108-17.

15. Utami W, Chotib A. Studi Kinerja PT BNI Syariah Sesudah Pemisahan (Spin Off) Dari Pt Bank Bni (Persero) Tbk. Akuntabilitas. 2014;VII(2):94-108.

16. Dulal M, Suzuki Y. Transcending the Trend of Financialization: The Heterodox vs. Islamic Economics View. Econ Soc Thought. 2015;2(4):226-41.

17. Safrilsyah. PERGURUAN TINGGI ISLAM DI ERA KONVERSI IAIN KE UIN: UPAYA INTEGRITAS KAJIAN ILMU AGAMA DAN UMUM. SUBSTANTIA. 2010;12(1):129-40.

18. Mursid A, Suhartono E. Faktor Determinan Nasabah dalam Pemilihan Bank Syariah. J Din Manaj. 2014;5(4):45-58.

19. Nugroho L, Tamala D. Persepsi pengusaha umkm terhadap peran bank syariah. J SIKAP (Sistem Informasi, Keuangan, Audit Dan Perpajakan). 2018;3(1):49-62.

20. Kwong MZ, Candinegara I. Relationship between Brand Experience, Brand Personality, Consumer Satisfaction, and Consumer Loyalty of DSSMF Brand. iBuss Manag. 2014;2(2):89-98.

21. Prihandono APP. Analisis pengaruh pengetahuan, religiusitas dan motif rasional terhadap proses keputusan dosen menggunakan Bank Syariah (studi kasus pada dosen di UIN Syarif Hidayatullah Jakarta. UIN Syarif Hidayatullah Jakarta; 2017.

22. Awan AG, Azhar M. CONSUMER BEHAVIOUR TOWARDS ISLAMIC BANKING IN PAKISTAN. Eur J Account Audit Financ Res. 2014;2(9):42-65.

23. Chong BS, Liu M. Islamic banking: Interest-free or interest-based? Pacific-Basin Financ J [Internet]. 2009;17(1):125-44. Available from: http://dx.doi.org/10.1016/j.pacfin.2007.12.003

24. Arianto DAN. SISTEM PERBANKAN ISLAM DAN PERKEMBANGANNYA DI INDONESIA. J Din Ekon BISNIS. 2010;7(1):47-56.

25. Aziz RM. NEW PARADIGM ON SINLAMMIM KAFAH IN ISLAMIC ECONOMICS. Roikhan Mochamad Aziz. 2012;1(2):139-48.

26. Aziz RM, Jayaprawira AR, Sulistyowati. Determinant of Islamic Pension Fund In 
Indonesia. Int J Islam Bus Econ. 2015;(Juni):68-81.

27. Nugroho L, Anisa N. Pengaruh Manajemen Bank Induk, Kualitas Aset, dan Efisiensi terhadap Stabilitas Bank Syariah di Indonesia (Periode Tahun 2013-2017) [Internet]. Vol. 6, Jurnal Inovasi dan Bisnis. 2018. Available from: www.ejournal.polbeng.ac.id/index.php/IBP

28. Metawa SA, Almossawi M. Banking behavior of Islamic bank customers : perspectives and implications. Int J Bank Mark. 2009;16(7):299-313.

29. Awan HM, Khuram SS. Customer' s criteria for selecting an Islamic bank : evidence from Pakistan. J Islam Mark. 2011;2(1):14-27.

30. Ahmad N, Haron S. PERCEPTIONS OF MALAYSIAN CORPORATE CUSTOMERS TOWARDS ISLAMIC BANKING PRODUCTS \& SERVICES. Int J Islam Financ Serv. 2000;3(4). 